\title{
Shear Strength of Hybrid Fibre-Reinforced Ternary Blend Geopolymer Concrete Beams under Flexure
}

\author{
V. Sathish Kumar $1, * \mathbb{D}$, N. Ganesan ${ }^{2}$ and P. V. Indira ${ }^{2}$ \\ 1 Faculty of Civil Engineering, Architecture and Geodesy, University of Split, 21000 Split, Croatia \\ 2 Department of Civil Engineering, National Institute of Technology Calicut, Kozhikode 673601, India; \\ ganesan@nitc.ac.in (N.G.); indira@nitc.ac.in (P.V.I.) \\ * Correspondence: skumarv@gradst.hr; Tel.: +91-9952-0936-68
}

check for updates

Citation: Sathish Kumar, V.;

Ganesan, N.; Indira, P.V. Shear Strength of Hybrid Fibre-Reinforced Ternary Blend Geopolymer Concrete Beams under Flexure. Materials 2021, 14, 6634. https://doi.org/10.3390/ ma14216634

Academic Editor: Sukhoon Pyo

Received: 5 September 2021

Accepted: 30 October 2021

Published: 3 November 2021

Publisher's Note: MDPI stays neutral with regard to jurisdictional claims in published maps and institutional affiliations.

Copyright: (c) 2021 by the authors. Licensee MDPI, Basel, Switzerland. This article is an open access article distributed under the terms and conditions of the Creative Commons Attribution (CC BY) license (https:/ / creativecommons.org/licenses/by/ $4.0 /)$.

\begin{abstract}
The need to promote sustainable civil infrastructure is one of the most important concerns in the construction industry. Geopolymer composites are one of the promising eco-friendly materials for the development of low carbon concrete. The main objective of this experimental investigation is to study the effect of hybrid fibres on the shear strength of flexural members made with ternary blend geopolymer concrete (TGPC). A total number of 27 reinforced concrete beams of size $100 \mathrm{~mm} \times 150 \mathrm{~mm} \times 1200 \mathrm{~mm}$ were cast and tested for shear. M55 grade of concrete was considered in this study. Crimped steel fibres and polypropylene fibres with an aspect ratio of 66 and 300, respectively, were used in this work. The main variables considered in this investigation involve two volume proportions of steel fibres, viz., $0.5 \%$ and $1 \%$ as well as four volume proportions of polypropylene fibres viz., $0.1 \%, 0.15 \%, 0.2 \%$ and $0.25 \%$. The hybrid fibre-reinforced ternary blend geopolymer concrete (HTGPC) beams were compared with TGPC beams without fibres. From the test results, it was clear that incorporating hybrid fibres improved the shear strength and changed the type of failure of the beam from shear to flexure. Moreover, a method to predict the ultimate shear strength of HTGPC was proposed, and the estimated values were found to be the same as the test results.
\end{abstract}

Keywords: beam; geopolymer concrete; hybrid fibre-reinforced concrete; shear strength; ternary blend

\section{Introduction}

Geopolymer concrete (GPC) is a new environmentally friendly material that reduces the global warming of the Earth and the greenhouse effect by replacing ordinary Portland cement (OPC). Portland cement is not considered a sustainable material due to the emission of a substantial amount of carbon dioxide $\left(\mathrm{CO}_{2}\right)$ into the atmosphere during its production [1-3]. GPC developed by Davidovits provides a suitable replacement for conventional concrete $[4,5]$. GPC is produced from an aluminosilicate source material using alkaline activators. It reduces the $\mathrm{CO}_{2}$ footprint and effectively utilises industrial wastes such as silica fumes, fly ash, ground granulated blast furnace slag (GGBS), etc. GPC has excellent mechanical properties and better fire resistance than conventional cement concrete. It reduces the carbon footprint and saves water for curing since the strength of GPC is from the polymerisation process, while the strength of OPC is due to the hydration of cement [6]. Ternary blend geopolymer concrete (TGPC) is developed by mixing three different source materials of varying particle sizes to form a denser concrete, resulting in improved properties compared to GPC $[7,8]$. Many researchers, aiming to provide knowledge about the effect of such concrete as structural elements, have discussed the structural behaviour of reinforced GPC members. Sofi et al. [9] studied the bond behaviour of geopolymer concrete with a steel bar by performing the direct pull-out test and the beam-end test. They concluded that the development length for GPC could be predicted using the equations provided in the standards for normal concrete. Sumajouw et al. [10] studied the effect of tensile reinforcement ratio on the behaviour of reinforced GPC and 
reported that the flexural capacity and ductility index are similar to conventional cement concrete. Many other studies also highlighted that the GPC beams performed similarly to conventional reinforced concrete under flexure [11-14].

A lot of research has been performed to explore the effect of fibres on the mechanical properties of concrete [15-17]. Naaman and Reinhardt [18] reported that adding a little fraction of short Torex fibres, which are engineered to achieve optimal properties in the order of $0.5 \%$ to $1 \%$ by volume, in concrete could enhance the toughness in the post-cracking response by bridging across the cracks. In the hybrid fibres system, the short fibres can bridge across the microcracks while the long fibres are more effective at controlling the progression of macrocracks [19-22]. The advantages of having a combination of metallic and non-metallic fibres in cement concrete are improving the mechanical properties and reducing the total cost of the concrete [23-25]. Navid et al. [26] studied the fibre-matrix interaction of fly ash-based GPC incorporated with steel and polypropylene fibres. They reported that the fibres played a vital role in the interfacial bond and improved properties such as energy absorption and flexural strength. Attempting to improve the tensile behaviour of high strength concrete has recently been gaining importance among researchers. High-performance fibre-reinforced concrete is a recently developed concrete that possesses high strength and ductility for use in structures where bending is dominant. Doo-Yeol et al. [27] investigated the effect of fibre length and placement method on the flexural behaviour of ultra-high-performance fibre-reinforced concrete (UHPFRC). They reported that the fibres placed in the centre exhibited higher flexural strength since more fibres existed in the crack plane. The material and bond properties of UHPFRC with micro steel fibres were reported by Doo-Yeol et al. [28]. They found that the CMR model was appropriate for predicting the ascending portion of the bond stress-slip response between the UHPFRC and the steel rebar. Umberto et al. [29] developed a numerical model for tracing the structural response of steel bar-reinforced UHPFRC enhanced with nanomaterials.

Several studies were carried out in the past on fibre-reinforced concrete beams without stirrups for normal concrete, high strength and high-performance concrete (HPC), and the studies proved the efficiency of the fibres in increasing the shear strength [30,31]. Victor et al. [32] examined the ultimate shear strength of fibre-reinforced mortar and concrete beams without stirrups and noted that the fibres prevented the shear failure. Many authors proposed empirical equations for predicting the ultimate shear strength for fibre-reinforced cement concrete [30,33-35]. Ambily et al. [36] and Ganesan et al. [37] reported the response of geopolymer concrete beams tested under shear and the effect of steel fibres on the shear strength of beams. All these works are limited to normal concrete, HPC, UHPFRC and fly ash-based GPC composites. However, studies on the behaviour of hybrid fibre-reinforced ternary blend geopolymer concrete (HTGPC) beams under shear are not yet reported. Hence, in this study, an attempt is made to analyse the shear strength of TGPC due to the influence of hybrid fibres.

\section{Experimental Programme}

\subsection{Materials}

The primary source material for the TGPC used in this work was low-calcium class F fly ash procured from Mettur Thermal Power Station in Tamil Nadu, India, conforming to the requirements of IS 3812:2003 [38]. Its chemical composition includes $\mathrm{Al}_{2} \mathrm{O}_{3}(27.75 \%)$ and $\mathrm{SiO}_{2}(55.36 \%)$. It is a dark grey powder and has a specific gravity of 2.30 . The average size of the fly ash particle is 75 microns. GGBS consisting of $77.37 \%$ of total $\mathrm{CaO}, \mathrm{MgO}$ and $\mathrm{SiO}_{2}$ conforming to BS 6699:1992 [39] was also used as one of the source materials. The colour of GGBS is off-white and has a specific gravity of 2.88 . The mean particle size of GGBS is 30 microns. Metakaolin procured from the local supplier was used as a third precursor for the TGPC. It has a specific gravity of 2.56 with a creamish-ivory powder appearance. It is composed of $92 \%$ of combined $\mathrm{SiO}_{2}, \mathrm{Al}_{2} \mathrm{O}_{3}$ and $\mathrm{Fe}_{2} \mathrm{O}_{3}$ elements. The average particle size of metakaolin is $2-3$ microns. These three materials were combined to form a ternary binder for the TGPC. The detailed properties of the source materials and 
their morphological information were provided in the previous study performed by the authors [7,40].

Locally available crushed stone (M-Sand) passing through a $4.75 \mathrm{~mm}$ (No.4) IS sieve conforming to Zone II of IS 383:1970 (reaffirmed 2002) [41] with a fineness modulus and specific gravity of 2.92 and 2.39 was used as fine aggregate. Coarse aggregate with a maximum size of $12.5 \mathrm{~mm}$ with a fineness modulus and specific gravity of 6.92 and 2.78 was also used. A blend of sodium hydroxide $(\mathrm{NaOH})$ in pellet form with $99 \%$ purity and a sodium silicate $\left(\mathrm{Na}_{2} \mathrm{SiO}_{3}\right)$ solution consisting of $8 \%$ of $\mathrm{Na}_{2} \mathrm{O}, 28 \%$ of $\mathrm{SiO}_{2}$ and $64 \%$ of water by mass was used as an alkaline activator. Naphthalene-based water reducing admixture, Conplast SP 430, was added for better workability. The hybrid fibres used in this study consist of (i) crimped steel fibres with a length of $30 \mathrm{~mm}$ and $0.45 \mathrm{~mm}$ diameter and (ii) polypropylene fibres having a length of $12 \mathrm{~mm}$ and 40 micron diameter. Figure 1 shows images of the steel and polypropylene fibres added in the mixture. The ultimate tensile strength of the steel and polypropylene fibres was $800 \mathrm{MPa}$ and $600 \mathrm{MPa}$, respectively.

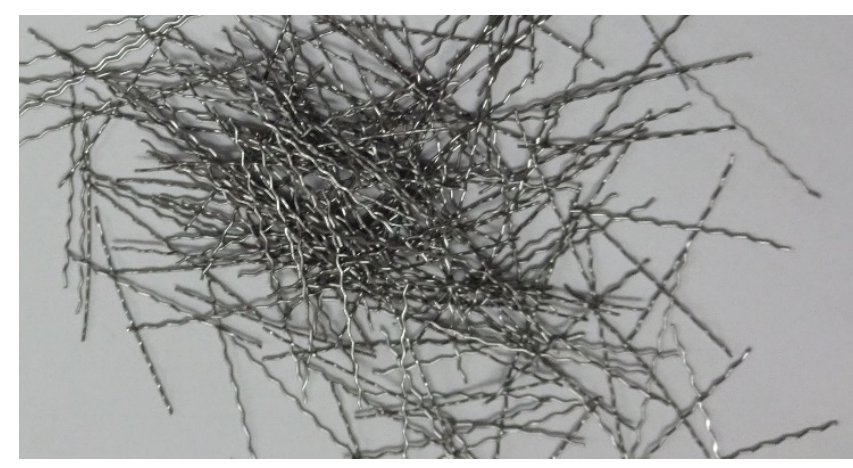

(a)

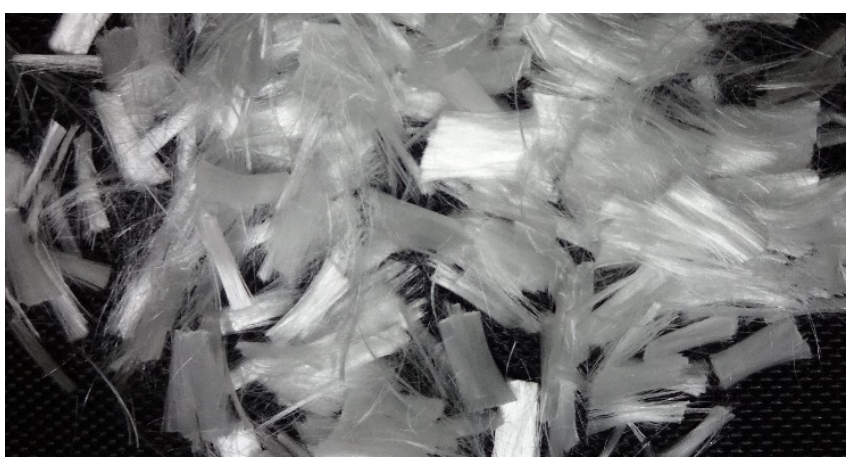

(b)

Figure 1. Fibres used: (a) crimped steel fibres; (b) polypropylene fibres.

\subsection{Mix Proportions for TGPC}

As standard mix design is not available for geopolymer concrete, the TGPC mix proportion for M55 concrete was arrived at by trial and error based on Rangan's recommendations [42]. The proportion of fly ash, GGBS and metakaolin the alkaline activator-to-binder ratio and the molarity of $\mathrm{NaOH}$ were obtained from the detailed studies carried out by the authors, which are presented elsewhere $[40,43]$ and are used in the present experimental investigation. Thus, the TGPC consists of $60 \%$ fly ash, $25 \%$ GGBS and $15 \%$ metakaolin. Moreover, the alkaline activator-to-binder ratio was selected as 0.3 , and the molarity of $\mathrm{NaOH}$ was maintained as $14 \mathrm{M}$. The water-to-binder ratio was kept constant at 0.2. Superplasticiser was added to the mix by $1.5 \%$ of the binder's total weight for better workability. The summary of the TGPC mix proportion is provided in Table 1 . The fibres were added to the same mix proportion at different levels to study their effect on the concrete.

Table 1. Mix proportion of ternary blend geopolymer concrete.

\begin{tabular}{cc}
\hline Materials & Quantity, $\mathbf{~ k g} / \mathbf{m}^{\mathbf{3}}$ \\
\hline Fly ash & 237.47 \\
GGBS & 122.61 \\
Metakaolin & 64.53 \\
Coarse aggregate & 1293.60 \\
Fine aggregate & 554.40 \\
$\mathrm{NaOH} \mathrm{Holution}_{2}$ & 36.40 \\
$\mathrm{Na}_{2} \mathrm{SiO}_{3}$ & 90.99 \\
Superplasticizer & 6.37 \\
Water & 84.92 \\
\hline
\end{tabular}




\subsection{Specimen Details}

The shear behaviour of HTGPC beams under flexure was studied by casting and testing 27 reinforced concrete beams of size $100 \times 150 \times 1200 \mathrm{~mm}^{3}$ with different volume fractions of fibres. Three specimens were tested for each combination of fibres and the average of the results was taken for analysis. The details of reinforcement of the specimen and the dimensions are provided in Figure 2. Two nos. of $10 \mathrm{~mm}$ diameter high yield strength deformed (HYSD) bars and two nos. of $6 \mathrm{~mm}$ diameter bars were provided at the bottom and top of the beam, respectively. The properties of the reinforcing bars are given in Table 2. Two-legged stirrups were provided using a $6 \mathrm{~mm}$ diameter bar at the loading and supporting points. No shear reinforcement was provided in the shear span to ensure shear failure [37].

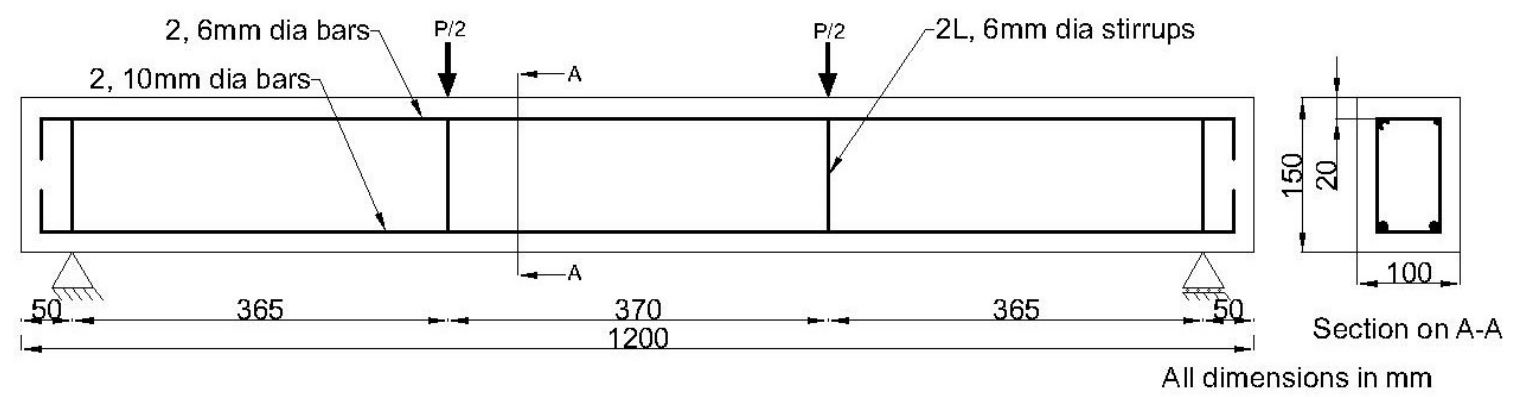

Figure 2. Reinforcement details of the specimen.

Table 2. Properties of steel bars.

\begin{tabular}{ccccc}
\hline $\begin{array}{c}\text { Nominal Diameter of Bar, } \\
\mathbf{m m}\end{array}$ & $\begin{array}{c}\text { Actual Diameter of Bar, } \\
\mathbf{M m}\end{array}$ & $\begin{array}{c}\text { Yield Strength, } \\
\mathbf{M P a}\end{array}$ & $\begin{array}{c}\text { Ultimate Strength, } \\
\mathbf{M P a}\end{array}$ & $\begin{array}{c}\text { Modulus of Elasticity, } \\
\text { GPa }\end{array}$ \\
\hline 10 & 9.97 & 534 & 584 & 244 \\
6 & 6.09 & 526 & 578 & 232 \\
\hline
\end{tabular}

\subsection{Mixing, Casting and Curing Procedure}

The test specimens were prepared using the dry materials in the horizontal drum-type concrete mixture, including ternary source material, coarse aggregates and fine aggregates. The $\mathrm{NaOH}$ pellets were mixed with water to prepare a $14 \mathrm{M}$ solution, and then a $\mathrm{Na}_{2} \mathrm{SiO}_{3}$ solution was added to it to form the alkaline activator $24 \mathrm{~h}$ before casting. The ratio of $\mathrm{Na}_{2} \mathrm{SiO}_{3}$ to $\mathrm{NaOH}$ by weight was kept constant at 2.5:1. While preparing the dry mixture, polypropylene fibres were added to the mix for the uniform distribution of fibres. Superplasticiser, alkaline activator and water were added to the dry mix, followed by the steel fibres. The reinforcement cage was kept inside the steel mould; the mixture was then poured in three layers into the mould and vibrated using a needle vibrator for better compaction. The top surface was smoothened using a trowel and covered with plastic film to avoid moisture loss while curing. After $24 \mathrm{~h}$ of rest, the beams were cured at $60^{\circ} \mathrm{C}$ for the next $24 \mathrm{~h}$ inside the steam-curing chamber. The samples were left at room temperature until testing.

\subsection{Testing}

The beams were whitewashed and then tested after 28 days under a four-point loading method to observe the crack patterns. The beams were tested in a compression and bending testing machine (GDR, Blue Star Engg. Co. Pvt. Ltd., Madras, India) of 3000 kN capacity at a constant loading rate of $4 \mathrm{kN} / \mathrm{min}$ until failure. The test was conducted in a loadcontrolled test setup and necessary precautions were taken to keep a constant loading rate. The deformations were observed by using electrical gadgets such as LVDTs, so that at every stage of application of loading the time taken for the observation was minimal. Two 
LVDTs with a least count of 1 micron were fixed at the top and bottom of the mid-span. The deformation at the mid-span was noted using a dial gauge having the least count of $0.01 \mathrm{~mm}$ and $25 \mathrm{~mm}$ travel. A crack width microscope with the least count of $0.02 \mathrm{~mm}$ was used to observe the cracks developed in the specimens. The readings were taken at each load increment of $2 \mathrm{kN}$ during the test. The actual test setup is shown in Figure 3.

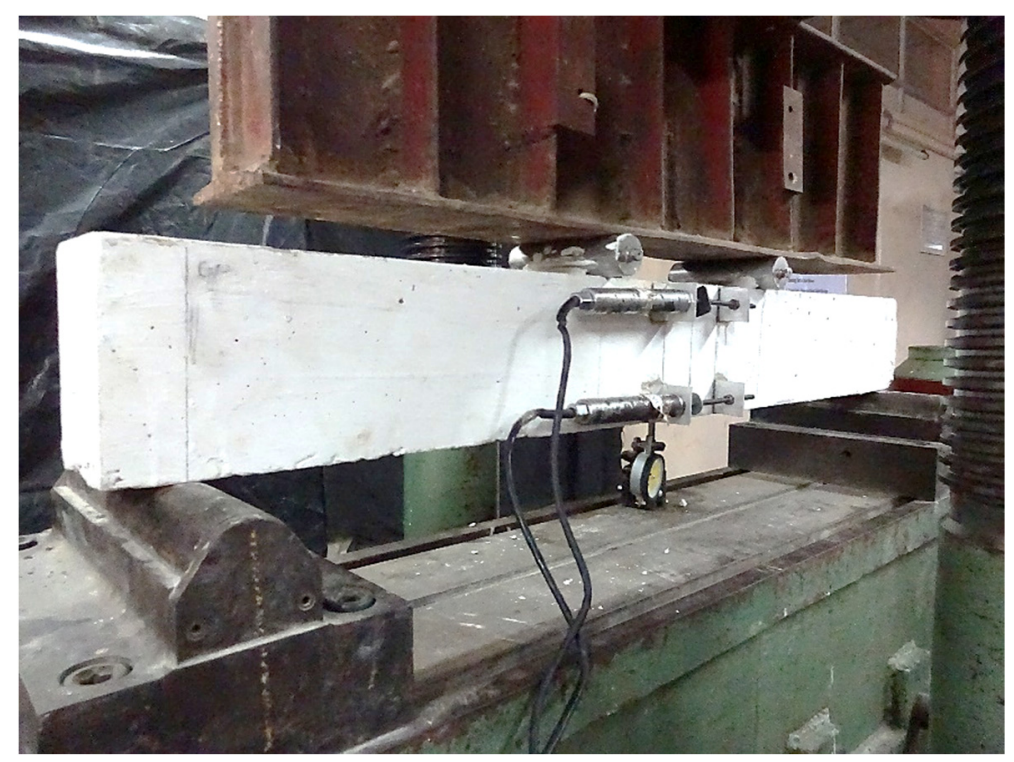

Figure 3. Actual test setup.

\section{Results and Discussions}

The test results of the beams are shown in Table 3. The values given in the table are the average of three identical beams tested with the same fibre content and loading condition.

Table 3. Test results.

\begin{tabular}{|c|c|c|c|c|c|c|c|c|c|}
\hline \multirow{2}{*}{ Specimen } & \multicolumn{2}{|c|}{ Volume Fraction, $\%$} & \multirow{2}{*}{$\begin{array}{l}\text { Compressive } \\
\text { Strength, } \\
\mathrm{MPa}\end{array}$} & \multirow{2}{*}{$\begin{array}{c}\text { Split } \\
\text { Tensile } \\
\text { Strength, } \\
\text { MPa }\end{array}$} & \multirow{2}{*}{$\begin{array}{c}\text { Flexural } \\
\text { Strength, } \\
\mathrm{MPa}\end{array}$} & \multirow{2}{*}{$\begin{array}{c}\text { First Crack } \\
\text { Load, kN }\end{array}$} & \multirow{2}{*}{$\begin{array}{l}\text { Ultimate } \\
\text { Load, kN }\end{array}$} & \multirow{2}{*}{$\begin{array}{l}\text { Deflection } \\
\text { at Ultimate } \\
\text { Load, } \mathrm{mm}\end{array}$} & \multirow{2}{*}{$\begin{array}{c}\text { Ultimate } \\
\text { Shear } \\
\text { Strength } \\
\text { MPa }\end{array}$} \\
\hline & $V_{s}$ & $V_{p}$ & & & & & & & \\
\hline TGPC & 0 & 0 & 57.23 & 4.72 & 5.62 & 14 & 39 & 3.82 & 2.60 \\
\hline HTGPC1 & \multirow{4}{*}{0.5} & 0.1 & 61.47 & 6.00 & 6.48 & 16 & 44 & 4.74 & 2.93 \\
\hline HTGPC2 & & 0.15 & 61.77 & 6.12 & 6.52 & 18 & 46 & 4.86 & 3.07 \\
\hline HTGPC3 & & 0.2 & 61.21 & 6.25 & 6.54 & 19 & 47 & 5.04 & 3.13 \\
\hline HTGPC4 & & 0.25 & 62.23 & 6.37 & 6.58 & 18 & 45 & 4.56 & 3.00 \\
\hline HTGPC5 & \multirow{4}{*}{1} & 0.1 & 66.93 & 6.27 & 7.76 & 25 & 52 & 6.82 & 3.47 \\
\hline HTGPC6 & & 0.15 & 65.77 & 6.32 & 7.85 & 26 & 54 & 8.52 & 3.60 \\
\hline HTGPC7 & & 0.2 & 64.09 & 6.48 & 7.80 & 24 & 53 & 7.26 & 3.47 \\
\hline HTGPC8 & & 0.25 & 64.80 & 6.56 & 7.71 & 23 & 50 & 6.63 & 3.33 \\
\hline
\end{tabular}

\subsection{Load-Deformation Characteristics}

The load-deflection curves for TGPC and HTGPC beams are shown in Figure 4. It can be noted that the linearity of the curves for all the specimens deviates after the first crack load. After the first crack load, multiple cracks were formed and the slope of the curve reduced and became nonlinear [44]. The HTGPC beams show a more or less flat portion of the curve beyond the ultimate load. In contrast, a sudden fall in the load was observed after the ultimate load for the TGPC beams without hybrid fibres. From the figure, it can be observed that the first stage was linear up to the formation of the first crack. After the initial crack, the beams underwent post-cracked behaviour and the load-deformation curve behaved nonlinearly until the peak load. The initiation of 
inclined cracks was influenced by strain-softening of tensile concrete, but in the progressive development of diagonal cracks the dowel action of steel bars and the fibres appeared to predominate [45]. It can also be noted from the figure that the HTGPC beams with $0.5 \%$ steel fibres exhibited improved deformation with the addition of polypropylene fibres up to $0.2 \%$. In comparison, the deformation of HTGPC beams with $1 \%$ steel fibres improved up to $0.15 \%$ polypropylene fibres. It can be observed that the further addition of polypropylene fibres resulted in reduced deformation; this is due to poor workability in the TGPC mixture with a high content of hybrid fibres [46]. In contrast, low hybrid fibre content resulted in only a marginal improvement in the behaviour of the HTGPC specimens with $0.5 \%$ steel fibres [47,48]. HTGPC beams with higher fibre proportion show less deformation for the same magnitude of the load, which shows the ductility increases due to the incorporation of hybrid fibres. HTGPC beams with a mix of $1 \%$ steel and $0.15 \%$ polypropylene fibre were found to perform better than all other specimens.

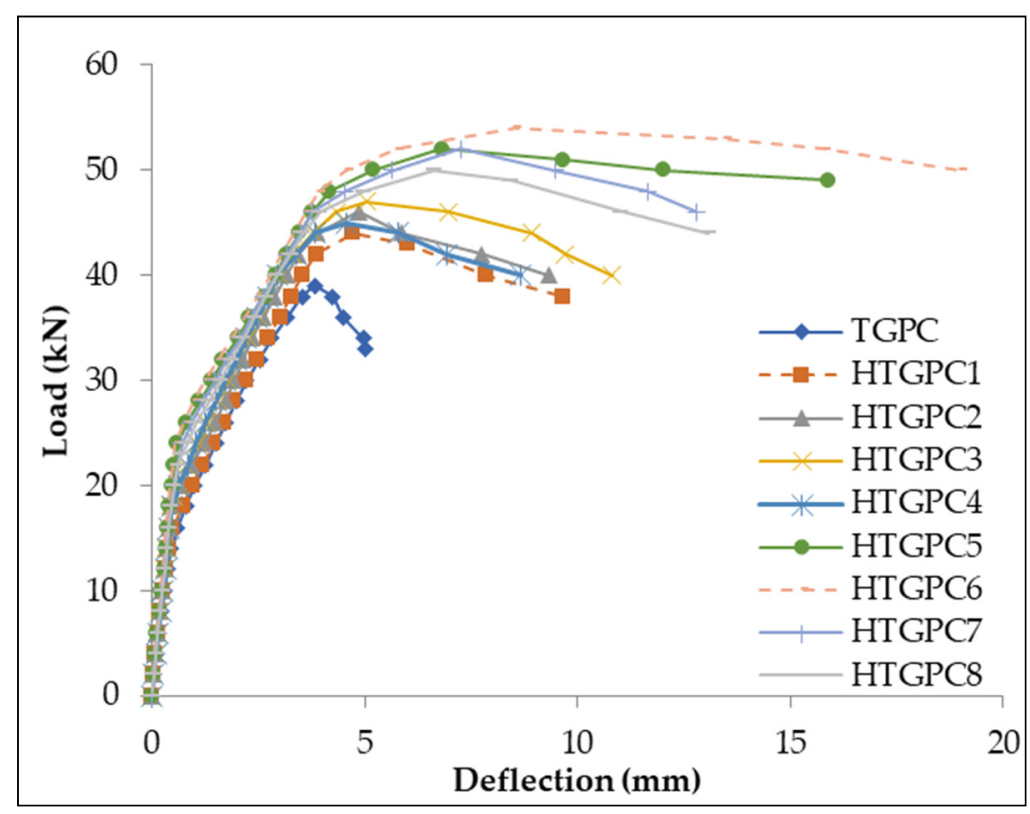

Figure 4. Load versus deflection plots.

\subsection{Cracking Behaviour and Failure Modes}

Figure 5 shows the crack patterns of the typical tested specimens after failure. Figure $5 \mathrm{a}$ shows that, in the plain TGPC beam, the first crack was initiated in the flexural span. When the load increased, diagonal cracks developed in the shear span and additional flexural cracks formed. As the load increased further, the existing cracks widened; at the final stage, the diagonal cracks developed faster, resulting in the beam's failure [49]. In the TGPC specimen, the failure occurred at the shear span when one of the diagonal cracks widened and reached the specimen's top. It can also be seen that, in a plain TGPC beam, the spalling of cover concrete occurred [50]. The addition of hybrid fibres in TGPC resulted in many finer cracks compared with specimens without fibres. In HTGPC specimens, the cracks were developed and widened at higher loads [51]. However, at corresponding loads, the crack widths of HTGPC specimens with 1\% steel fibres were $60 \%$ lower than the cracks formed in TGPC specimens, whereas the average crack width was $55 \%$ lower for the specimens with $0.5 \%$ steel fibres. It may also be noted that, in HTGPC specimens, the flexural cracks are more predominant than the cracks in the shear span. In general, the incorporation of hybrid fibres delayed the first crack, increased the shear strength and changed the failure mode from shear to flexure [44]. 


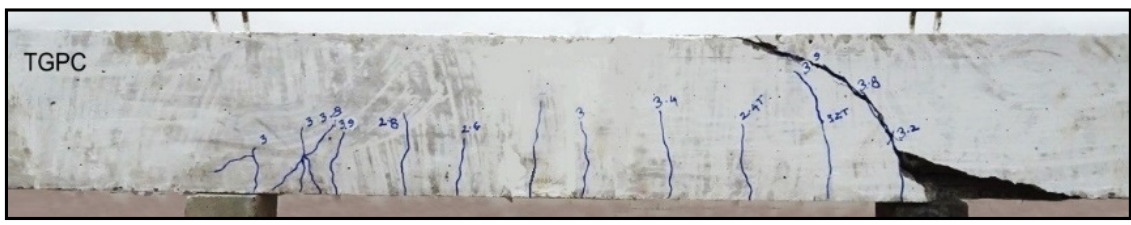

(a)

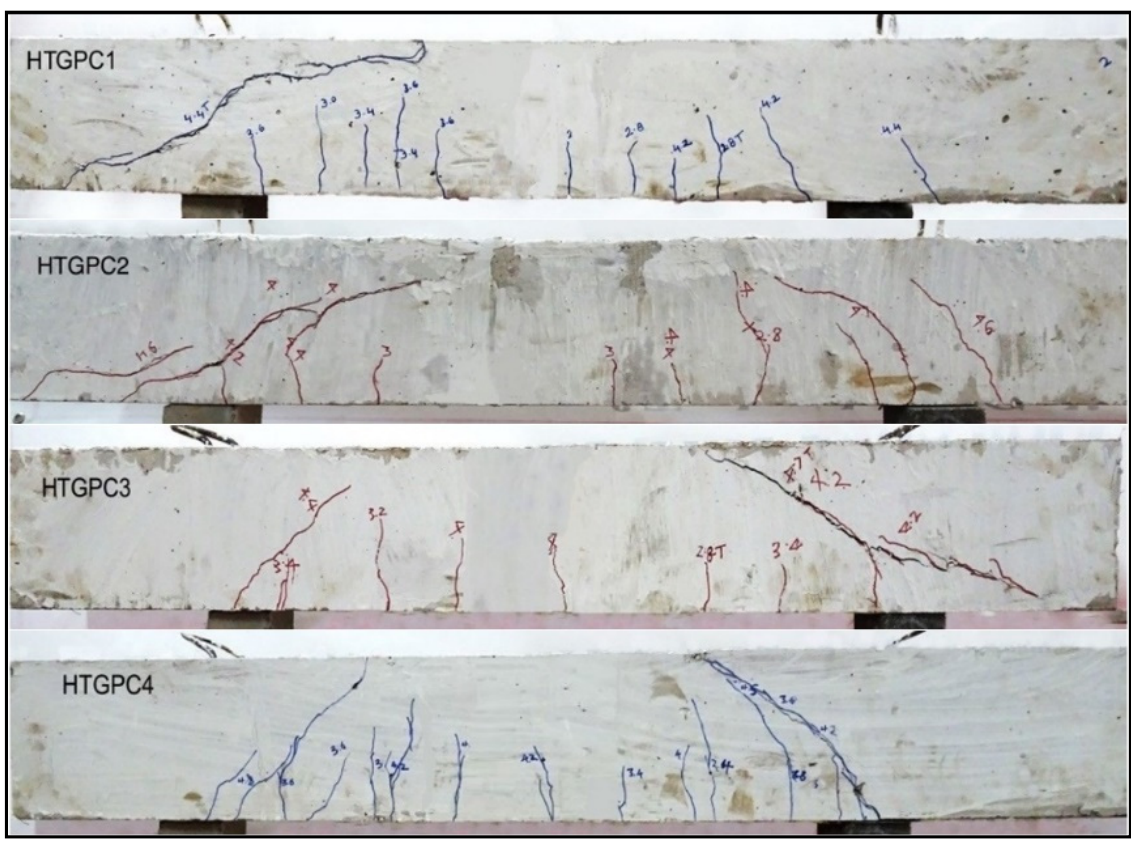

(b)

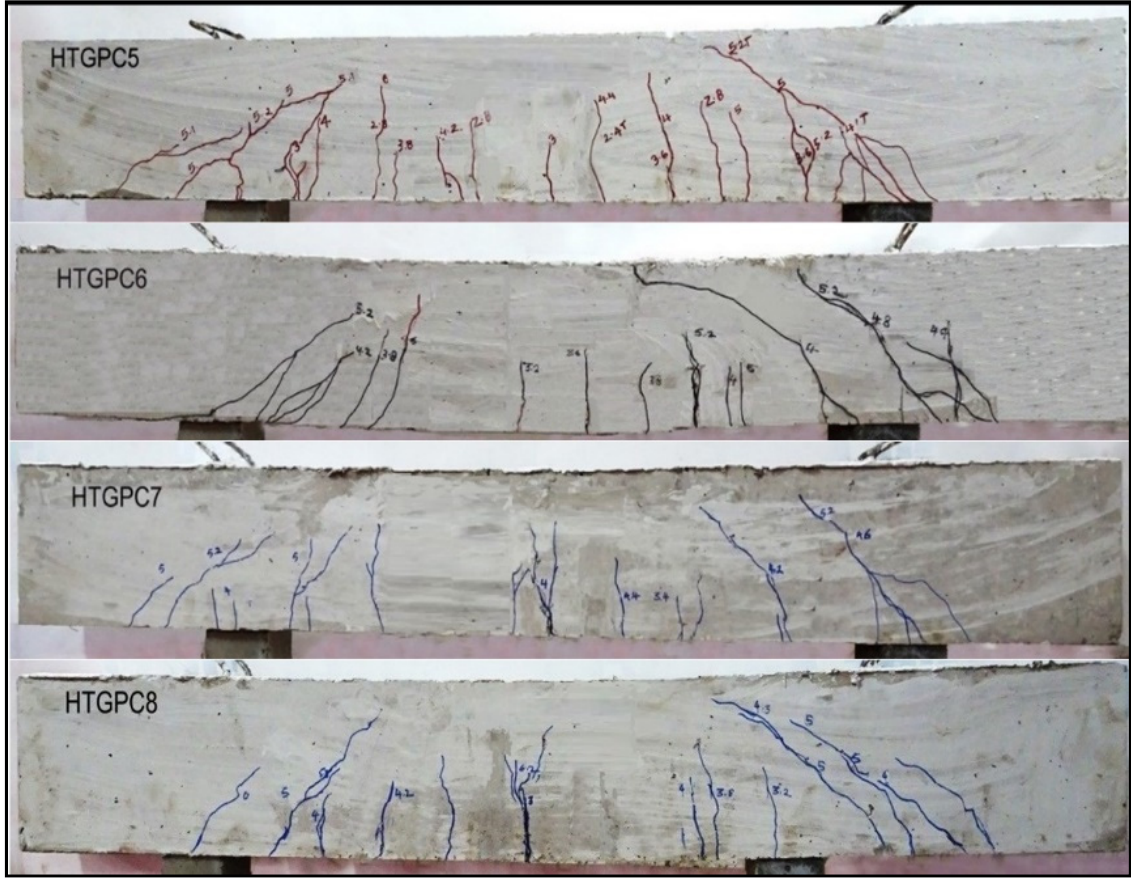

(c)

Figure 5. Crack pattern of typical tested beams: (a) TGPC beam; (b) HTGPC beams with $0.5 \%$ steel fibres; (c) HTGPC beams with $1 \%$ steel fibres. 


\subsection{Ultimate Shear Strength}

Table 3 shows the test results of the tested specimens. The beams with hybrid fibres show improved ultimate shear strength when compared with TGPC beams without fibres [52]. The ultimate shear strength for HTGPC beams with $1 \%$ steel and $0.15 \%$ polypropylene fibre increased by $38.46 \%$ compared with TGPC beams. This may be due to the prevention and deviation of cracks from their path by the fibres bridging across the cracks. Hence, for further propagation of cracks, the beams with fibres need more energy, which consecutively improves the beam's load-carrying capacity.

\section{Design Equations Available in the Literature for Shear Strength of Reinforced Concrete Flexural Members}

4.1. Ashour et al.

Ashour et al. [33] proposed an equation by considering various factors such as steel fibre content, shear span-to-depth ratio and longitudinal steel ratio to predict the shear strength of fibre-reinforced concrete beams.

- Modification of ACI building code equation:

The shear strength equation obtained by modifying the ACI Building Code equation is given by,

$$
V_{u}=\left(0.7 \sqrt{f_{c}^{\prime}}+7 F\right) \frac{d}{a}+17.2 \rho \frac{d}{a}
$$

- Modification of Zutty's equation:

Zutty's equation was modified by the factor $\mathrm{F}$ to account for fibres, and it is given as, For $a / d>2.5$,

$$
V_{u}=\left(2.11 \sqrt{f^{\prime}}+7 F\right)(\rho d / a)^{0.333}
$$

For $a / d>2.5$,

$$
V_{u}=\left[\left(2.11 \sqrt[3]{f^{\prime}}{ }_{c}+7 F\right)\left(\rho \frac{d}{a}\right)^{0.333}\right]\left[\frac{2.5 d}{a}+V_{b}\left(2.5-\frac{d}{a}\right)\right]
$$

\subsection{Kwak et al.}

Kwak et al. [34] considered different volume fractions of fibres and different shear span-to-depth ratio; the following equation was proposed to obtain the shear strength,

$$
V_{u}=3.7 e f_{c t}^{2 / 3}\left(\rho \frac{d}{a}\right)^{1 / 3}+0.8 V_{b}
$$

where:

$$
e=1.0 \text { for } a / d>3.4 \text { and } 3.4 d / a \text { for } a / d \leq 3.4
$$

\subsection{Li et al.}

Taking into account split tensile and flexural strength, as well as reinforcement ratio and shear span-to-depth ratio, the following equation was proposed by Li et al. [32] to determine the shear strength,

For $a / d>2.5$,

$$
V_{u}=1.25+4.68\left[\left(f_{f} f_{c t}\right)^{3 / 4}\left(\rho \frac{d}{a}\right)^{1 / 3}(d)^{-1 / 3}\right]
$$

For $a / d>2.5$,

$$
V_{u}=9.16\left[f_{c t}^{2 / 3} \rho^{1 / 3}\left(\frac{d}{a}\right)\right]
$$




\subsection{Narayanan and Darwish}

The equation developed for determining the shear strength of fibre-reinforced beam by Narayanan and Darwish [30] is given as,

$$
V_{u}=e\left(0.24 f_{c t}+80 \rho \frac{d}{a}\right)+V_{b}
$$

where:

$$
e=1.0 \text { for } a / d>2.8 \text { and } 2.8 d / a \text { for } a / d<2.8
$$

\subsection{Sharma}

Sharma [35] conducted tests with different types of fibres and proposed a model for predicting shear strength,

$$
V_{u}=\frac{2}{3} f_{c t}\left(\frac{d}{a}\right)^{0.25}
$$

The shear strength of the reinforced concrete beams with fibres can be obtained through two design approaches. The first approach uses an empirical equation developed to calculate the contribution of concrete and fibres to the shear strength of the beam. The second approach is more deterministic, where the contribution of fibres to shear strength is computed separately by toughness enhancement in flexure [53]. In this study, the first approach is adopted to calculate the shear strength of the TGPC beams with fibres. Table 4 shows the comparison of experimental shear strength $\left(V_{u(\exp )}\right)$ and theoretical shear strength $\left(V_{u(\text { the })}\right)$ values obtained from the literature. The mechanical properties of HTGPC with different volume fractions of hybrid fibres were obtained from the authors' detailed experimental work, which is presented elsewhere [7] and used in this present work. It can be observed that there is a variation between the practical and theoretical models in the literature. This inconsistency is due to the fact that all the equations available in the literature were obtained for conventional fibre-reinforced concrete. Therefore, an attempt was performed to modify one of the available equations, giving the low coefficient of variation for the ratio $V_{u(\text { exp })} / V_{u(\text { the) }}$. From the given equations, it is noted that the equation predicted by Li et al. [32] gives the low value of the coefficient of variation (4.76\%) and a mean value near $1.0(0.96)$. Since different variables such as aspect ratio of fibres, volumetric fraction of fibres and strength of concrete affect the test results, an attempt is

\begin{tabular}{|c|c|c|c|c|c|c|c|c|c|c|c|c|c|}
\hline \multirow{3}{*}{ Specimen } & \multirow[b]{2}{*}{$\begin{array}{c}V_{u(\exp )} \\
\mathrm{MPa}\end{array}$} & \multicolumn{6}{|c|}{$V_{u(\text { the })}, \mathrm{MPa}$} & \multicolumn{6}{|c|}{$V_{u(\exp )} / V_{u(\text { the })}$} \\
\hline & & $\begin{array}{l}\text { Ashour } \\
\text { et al.-I }\end{array}$ & $\begin{array}{l}\text { Ashour } \\
\text { et al.-II }\end{array}$ & $\begin{array}{c}\text { Kwak } \\
\text { et al. }\end{array}$ & $\begin{array}{c}\mathrm{Li} \\
\text { et al. }\end{array}$ & $\begin{array}{c}\text { Narayanan } \\
\text { and } \\
\text { Darwish }\end{array}$ & Sharma & Ratio & Ratio & Ratio & Ratio & Ratio & Ratio \\
\hline & i & ii & iii & iv & $\mathbf{v}$ & vi & vii & i/ii & i/iii & i/iv & $\mathbf{i} / \mathbf{v}$ & i/vi & i/vii \\
\hline TGPC & 2.60 & 1.62 & 1.23 & 1.76 & 2.86 & 1.38 & 2.17 & 1.60 & 2.12 & 1.47 & 0.91 & 1.89 & 1.20 \\
\hline HTGPC1 & 2.93 & 2.58 & 1.71 & 2.55 & 3.12 & 2.29 & 2.54 & 1.14 & 1.72 & 1.15 & 0.94 & 1.28 & 1.15 \\
\hline HTGPC2 & 3.07 & 2.76 & 1.80 & 2.69 & 3.15 & 2.45 & 2.59 & 1.11 & 1.71 & 1.14 & 0.97 & 1.25 & 1.18 \\
\hline HTGPC3 & 3.13 & 2.92 & 1.88 & 2.83 & 3.18 & 2.63 & 2.67 & 1.07 & 1.67 & 1.11 & 0.98 & 1.19 & 1.17 \\
\hline HTGPC4 & 3.00 & 3.10 & 1.97 & 3.04 & 3.30 & 2.86 & 2.86 & 0.97 & 1.52 & 0.99 & 0.91 & 1.05 & 1.05 \\
\hline HTGPC5 & 3.47 & 3.22 & 2.03 & 3.15 & 3.44 & 2.97 & 3.02 & 1.08 & 1.71 & 1.10 & 1.01 & 1.17 & 1.15 \\
\hline HTGPC6 & 3.60 & 3.37 & 2.11 & 3.28 & 3.45 & 3.12 & 3.05 & 1.07 & 1.71 & 1.10 & 1.04 & 1.15 & 1.18 \\
\hline HTGPC7 & 3.47 & 3.52 & 2.18 & 3.48 & 3.53 & 3.36 & 3.25 & 0.98 & 1.59 & 1.00 & 0.98 & 1.03 & 1.07 \\
\hline HTGPC8 & 3.33 & 3.70 & 2.27 & 3.62 & 3.57 & 3.52 & 3.30 & 0.90 & 1.47 & 0.92 & 0.93 & 0.95 & 1.01 \\
\hline \multirow{2}{*}{\multicolumn{8}{|c|}{ Average }} & 1.10 & 1.69 & 1.11 & 0.96 & 1.22 & 1.13 \\
\hline Coefficient of variation (\%) & & & & & & & & 18.4 & 10.9 & 14.2 & 4.76 & 22.4 & 6.14 \\
\hline
\end{tabular}
made to introduce a factor that accounts for the above parameters.

Table 4. Comparison of experimental values with theoretical values obtained from the literature. 
Hence, the equation of Li et al. [32] was modified further by introducing a factor $\left(F_{s}\right)$ that represents the combination of the above parameters. The equation for the correction factor $\left(F_{s}\right)$ is given below,

$$
F_{s}=A_{f_{s}} V_{s} d_{s} \eta_{b s}+A_{f p} V_{p} d_{p} \eta_{b p}
$$

where $\eta_{b s}$ and $\eta_{b p}$ are the bond efficiency factor taken as 1.2 for crimped steel fibres and 1.0 for round straight fibres, respectively [54]. From the calculated shear strength values using Equation (5), the ratios of $V_{u(\exp ) /} V_{u(\text { the) }}$ were obtained and related to $F s$ as given in Figure 6. The regression equation from the plot is,

$$
V_{u(\exp )} / V_{u(\text { the })}=-0.1062\left(F_{s}\right)^{2}+0.2615\left(F_{s}\right)+0.9062
$$

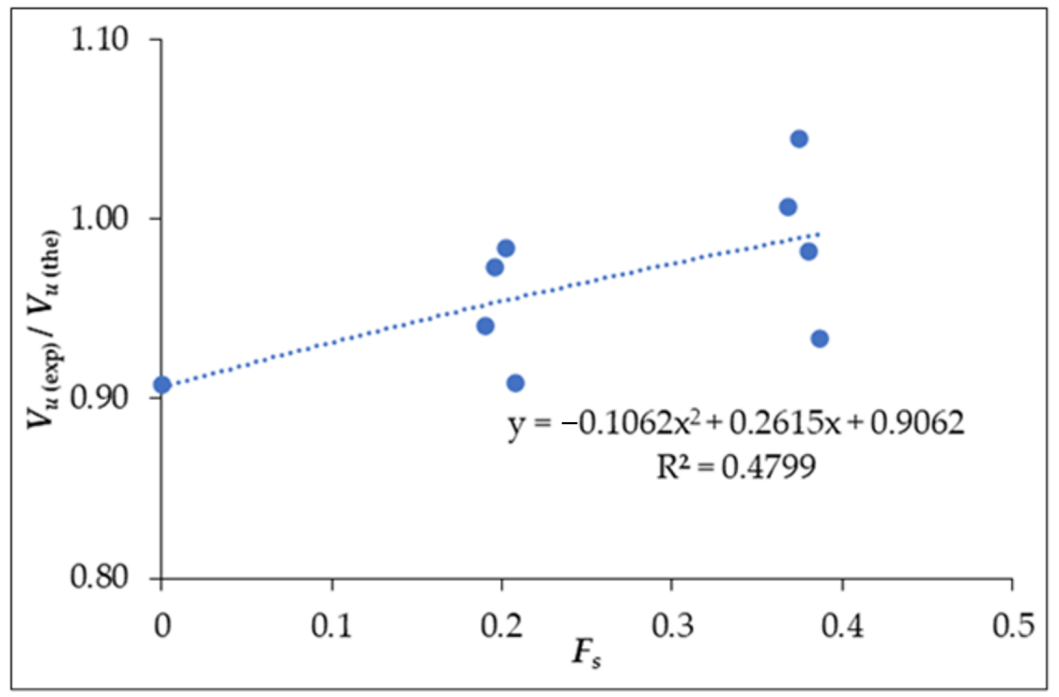

Figure 6. Correction factor $\left(F_{s}\right)$ against $V_{u(\exp ) /} V_{u(\text { the })}$.

To predict an equation for obtaining the ultimate shear strength of HTGPC beams $\left(V_{u(\text { pre) }}\right)$, Equation (10) is modified by replacing $V_{u(\text { exp) }}$ with $V_{u(\text { pre) }}$. Thus, the modified equation for predicting the shear strength of HTGPC is obtained as,

$$
V_{u(\text { pre })}=V_{u(\text { the })}\left(-0.1062\left(F_{s}\right)^{2}+0.2615\left(F_{s}\right)+0.9062\right)
$$

by substituting Equation (5) in the above Equation (11),

$$
V_{\mathrm{u}(\text { pre })}=1.25+4.68\left[\left(f_{f} f_{c t}\right)^{3 / 4}\left(\rho \frac{d}{a}\right)^{1 / 3}(d)^{-1 / 3}\right]\left(-0.1062\left(F_{s}\right)^{2}+0.2615\left(F_{s}\right)+0.9062\right)
$$

From Equation (12), the ultimate shear strength for all the beams was calculated and the results were compared with the experimental values. $V_{u(\text { pre) }}$ versus $V_{u(\exp )}$ values were plotted and are shown in Figure 7. It can be noted from Figure 7 that most of the points are lying near the line of equality and well inside the $\pm 10 \%$ lines of agreement. The coefficient of variation and $V_{u(\text { pre }) /} V_{u(\exp )}$ mean value are $3.70 \%$ and 1.0 . This shows that the predicted equation is found to correlate convincingly with the experimental test results. The experimental investigations note that HTGPC is an important alternative to cement concrete composites, which will lead to the development of sustainable composites. It can also be noted that the shear strength of the concrete can be improved, and the shear failure in reinforced concrete beams can be avoided with the incorporation of steel and polypropylene fibres. 


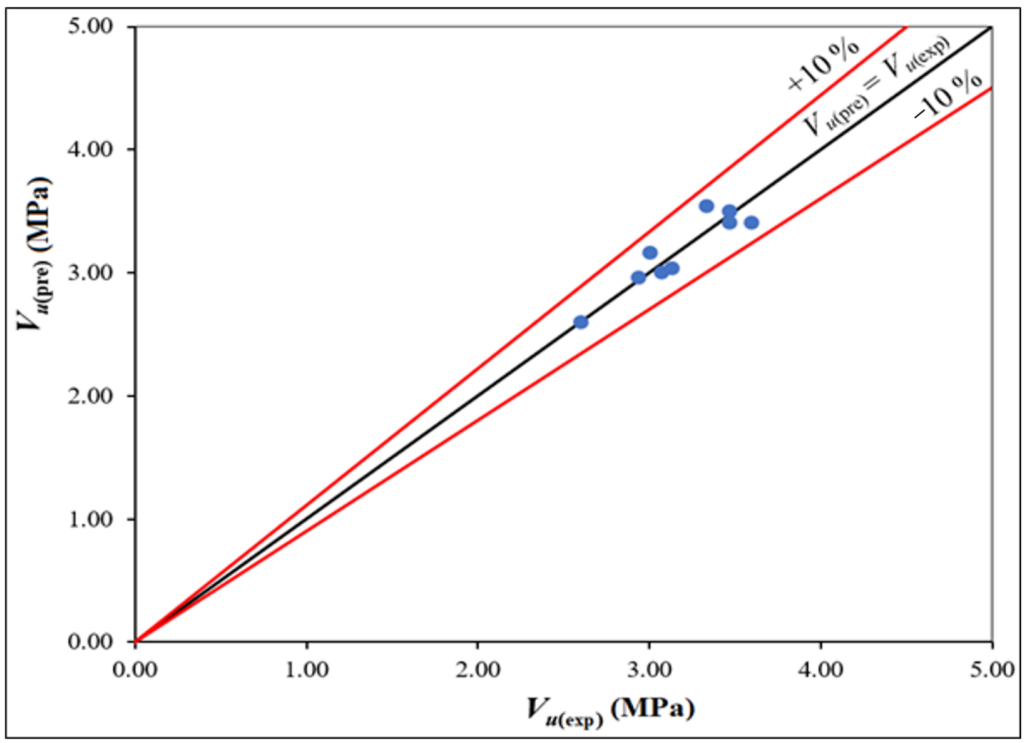

Figure 7. Comparison of experimental and predicted values of shear strength.

\section{Conclusions}

The following conclusions may be derived based on this experimental investigation into the shear strength of hybrid fibre-reinforced ternary blend geopolymer concrete beams under flexure:

1. The addition of hybrid fibres in TGPC beams modified the cracking pattern and failure from shear to flexure.

2. Due to hybrid fibres, the first crack load and ultimate shear strength of HTGPC beams were improved by up to $85 \%$ and $38.5 \%$, respectively, compared to the TGPC beams.

3. HTGPC specimens with a combination of $1 \%$ steel fibres and $0.15 \%$ polypropylene fibres showed better results and suffered higher deflections, indicating a relative increase in ductility compared with other specimens.

4. A method for predicting the ultimate shear strength for HTGPC was proposed to account for the effect of hybrid fibres in TGPC. The predicted values of the ultimate shear strength were found to compare convincingly with the experimental test results.

5. The modified equation for predicting the shear strength of HTGPC beams limits up to $1 \%$ steel and $0.25 \%$ polypropylene fibres. The obtained test results will be helpful in the rational design of HTGPC beams.

Author Contributions: Conceptualisation, N.G. and P.V.I.; supervision, N.G. and P.V.I.; methodology, N.G., P.V.I. and V.S.K.; experimental investigation, V.S.K.; writing-original draft preparation, V.S.K.; writing-review and editing, N.G. and P.V.I..; All authors have read and agreed to the published version of the manuscript.

Funding: This research received no external funding.

Institutional Review Board Statement: Not applicable.

Informed Consent Statement: Not applicable.

Data Availability Statement: Not applicable.

Conflicts of Interest: The authors declare no conflict of interest. The funders had no role in the design of the study; in the collection, analyses, or interpretation of data; in the writing of the manuscript, or in the decision to publish the results. 


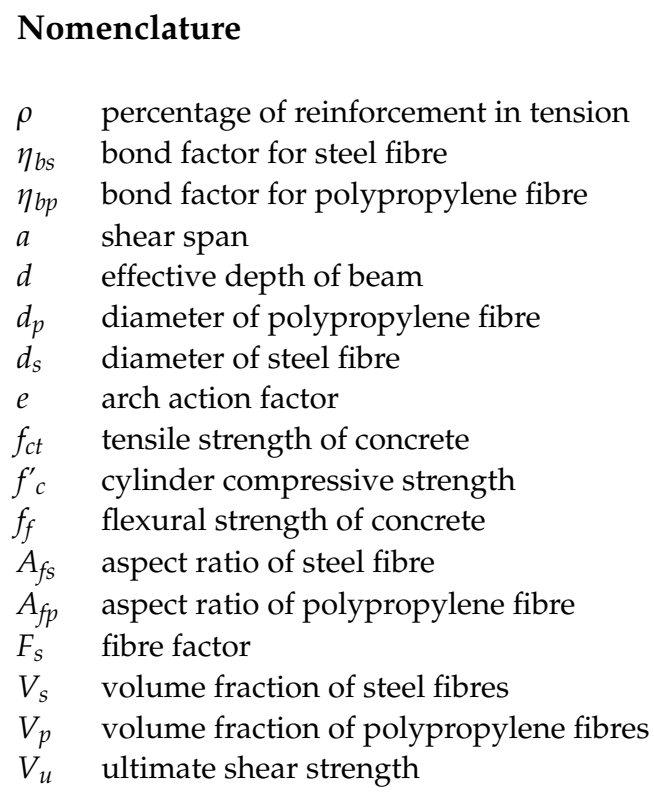

\section{References}

1. Mustafa Al Bakri, A.M.; Kamarudin, H.; Bnhussain, M.; Rafiza, A.R.; Zarina, Y. Effect of $\mathrm{Na}_{2} \mathrm{SiO}_{3} / \mathrm{NaOH}$ ratios and $\mathrm{NaOH}$ molarities on compressive strength of fly-ash-based geopolymer. ACI Mater. J. 2012, 109, 503-508.

2. Bondar, D.; Lynsdale, C.J.; Milestone, N.B.; Hassani, N.; Ramezanianpour, A.A. Engineering Properties of Alkali-Activated Natural Pozzolan Concrete. ACI Mater. J. 2011, 108, 64-72.

3. Singh, N.B.; Kumar, M.; Rai, S. Geopolymer cement and concrete: Properties. Mater. Today Proc. 2020, 29, 743-748. [CrossRef]

4. Davidovits, J. High-Alkali Cements for 21st Century Concretes. ACI J. 1994, 144, 383-398.

5. Luhar, S.; Nicolaides, D.; Luhar, I. Fire Resistance Behaviour of Geopolymer Concrete: An overview. Buildings 2021, 11, 82. [CrossRef]

6. Lingyu, T.; Dongpo, H.; Jianing, Z.; Hongguang, W. Durability of geopolymers and geopolymer concretes: A review. Rev. Adv. Mater. Sci. 2021, 60, 1-14. [CrossRef]

7. Sathish Kumar, V.; Ganesan, N.; Indira, P.V. Engineering Properties of Hybrid Fibre Reinforced Ternary Blend Geopolymer Concrete. J. Compos. Sci. 2021, 5, 203. [CrossRef]

8. Sathish Kumar, V.; Indira, P.V.; Ganesan, N. Tension stiffening and cracking behaviour of hybrid fibre reinforced ternary blend geopolymer concrete. J. Struct. Eng. 2019, 46, 257-266.

9. Sofi, M.; Van Deventer, J.S.J.; Mendis, P.A.; Lukey, G.C. Bond performance of reinforcing bars in inorganic polymer concrete (IPC). J. Mater. Sci. 2007, 42, 3107-3116. [CrossRef]

10. Sumajouw, M.D.J.; Rangan, B.V. Low-Calcium Fly Ash-Based Geopolymer Concrete: Reinforced Beams and Columns; Curtin University of Technology: Perth, Australia, 2006.

11. Kumaravel, S.; Thirugnanasambandam, S.; Jeyasehar, C.A. Flexural behaviour of geopolymer concrete beams with GGBS. IUP J. Struct. Eng. 2014, 7, 45-54.

12. Yodsudjai, W. Application of fly ash-based geopolymer for structural member and repair materials. Adv. Sci. Technol. 2014, 92, 74-83. [CrossRef]

13. Mathew, G.; Joseph, B. Flexural behaviour of geopolymer concrete beams exposed to elevated temperatures. J. Build. Eng. 2018, 15, 311-317. [CrossRef]

14. Ahmed, H.Q.; Jaf, D.K.; Yaseen, S.A. Comparison of the Flexural Performance and Behaviour of Fly-Ash-Based Geopolymer Concrete Beams Reinforced with CFRP and GFRP Bars. Adv. Mater. Sci. Eng. 2020, 2020, 3495276. [CrossRef]

15. Aldikheeli, M.R.; Shubber, M.S. The effects of fibre on the mechanical properties of aerated concrete. IOP Conf. Ser. Mater. Sci. Eng. 2020, 671, 012076. [CrossRef]

16. Ali, B.; Raza, S.S.; Hussain, I.; Iqbal, M. Influence of different fibers on mechanical and durabilityperformance of concrete with silica fume. Struct. Concr. 2021, 22, 318-333. [CrossRef]

17. Paul, S.C.; Van Zijl, G.P.A.G.; Savija, B. Effect of Fibers on Durability of Concrete: A Practical Review. Materials 2020, 13, 4562. [CrossRef]

18. Naaman, A.E.; Reinhardt, H.W. Proposed classification of HPFRC composites based on their tensile response. Mater. Struct. 2006, 39, 547-555. [CrossRef]

19. Yu, R.; Spiesz, P.; Brouwers, H.J.H. Static properties and impact resistance of a green Ultra-High Performance Hybrid Fibre Reinforced Concrete (UHPHFRC): Experiments and modeling. Constr. Build. Mater. 2014, 68, 158-171. [CrossRef]

20. Qian, C.; Stroeven, P. Fracture properties of concrete reinforced with steel-polypropylene hybrid fibers. Cem. Concr. Compos. 2000, 22, 343-351. [CrossRef] 
21. Raza, A.; Khan, Z. Experimental and numerical behavior of hybrid-fiber-reinforced concrete compression members under concentric loading. SN Appl. Sci. 2020, 2, 701. [CrossRef]

22. Das, S.; Rahman, H.; Tam, V.W.Y.; Sayed, A.; Akid, M.; Mohamed, N.; Rahman, F.M.M. Effects of incorporating hybrid fibres on rheological and mechanical properties of fibre reinforced concrete. Constr. Build. Mater. 2020, 262, 120561. [CrossRef]

23. Sivakumar, A.; Santhanam, M. Mechanical properties of high strength concrete reinforced with metallic and non-metallic fibres Cem. Concr. Compos. 2007, 29, 603-608. [CrossRef]

24. Sebastin, S.; Kumar, S.M.R.; David, M.F. Effect of Metallic and Non-Metallic Fibre and Recycled Aggregate on High Strength Concrete. IOP Conf. Ser. Mater. Sci. Eng. 2020, 1006, 012036. [CrossRef]

25. Najm, H.M.; Ahmad, S. The effect of metallic and non-metallic fiber on the mechanical properties of waste ceramic concrete. Innov. Infrastruct. Solut. 2021, 6, 204. [CrossRef]

26. Ranjbar, N.; Talebian, S.; Mehrali, M.; Kuenzel, C.; Simon, H.; Metselaar, C.; Zamin, M. Mechanisms of interfacial bond in steel and polypropylene fiber reinforced geopolymer composites. Compos. Sci. Technol. 2016, 122, 73-81. [CrossRef]

27. Yoo, D.; Kang, S.; Yoon, Y. Effect of fiber length and placement method on flexural behavior, tension-softening curve, and fiber distribution characteristics of UHPFRC. Constr. Build. Mater. 2014, 64, 67-81. [CrossRef]

28. Yoo, D.; Shin, H.; Yang, J.; Yoon, Y. Material and bond properties of ultra high performance fiber reinforced concrete with micro steel fibers. Compos. Part B 2014, 58, 122-133. [CrossRef]

29. De Maio, U.; Fantuzzi, N.; Greco, F.; Leonetti, L.; Pranno, A. Failure Analysis of Ultra High-Performance Fiber-Reinforced Concrete Structures Enhanced with Nanomaterials by Using a Di ff use Cohesive Interface Approach. Nanomaterials 2020, 10, 1792. [CrossRef] [PubMed]

30. Narayanan, R.; Darwish, I.Y.S. Use of steel fibers as shear reinforcement. ACI Struct. J. 1987, 84, $216-227$.

31. Cucchiara, C.; Mendola, L.L.; Papia, M. effectiveness of stirrups and steel fibres as shear reinforcement. Cem. Concr. Compos. 2004, 26, 777-786. [CrossRef]

32. Li, V.C.; Ward, R.; Hmaza, A.M. Steel and synthetic fibers as shear reinforcement. ACI Mater. J. 1992, 89, 499-508.

33. Ashour, S.A.; Hasanain, G.S.; Wafa, F.F. shear behavior of high-strength fiber reinforced concrete beams. ACI Struct. J. 1992, 89, 176-184.

34. Kwak, Y.K.; Eberhard, M.O.; Kim, W.S.; Kim, J. shear strength of steel fiber-reinforced concrete beams without stirrups. ACI Struct. J. 2002, 99, 530-538.

35. Sharma, A.K. shear strength of steel fiber reinforced concrete beams. ACI J. 1986, 83, 624-628.

36. Ambily, P.S.; Madheswaran, C.K.; Sharmila, S.; Muthiah, S. Experimental and analytical investigations on shear behaviour of reinforced geopolymer concrete beams. Int. J. Civ. Struct. Eng. 2011, 2, 682-697.

37. Ganesan, N.; Indira, P.V.; Santhakumar, A. Effect of steel fibres on shear strength of geopolymer concrete beams. J. Struct. Eng. 2015, 41, 441-448.

38. Pulvarized Fuel Ash-Specification; IS 3812:2003; Bureau of Indian Standards: New Delhi, India, 2003.

39. Ground Granulated Blast Furnace Slag for Use with Portland Cement-Specification; BS 6699:1992; British Standards Institution London: London, UK, 1992.

40. Ganesan, N.; Indira, P.V.; Sathish Kumar, V. Effect of Alkaline Activator to Binder Ratio on the Compressive Strength of Ternary Blend Geopolymer Concrete. ICI J. 2017, 17, 22-27.

41. Specification for Coarse and Fine Aggregates from Natural Sources for Concrete; IS 383:1970 (Reaffirmed 2002); Bureau of Indian Standards: New Delhi, India, 2002.

42. Rangan, B.V. Fly ash Based Geopolymer Concrete. In Proceedings of the International Workshop on Geopolymer Cement and Concrete, Mumbai, India, 7 December 2010; pp. 68-106.

43. Sathish Kumar, V.; Ganesan, N.; Indira, P.V. Effect of Molarity of Sodium Hydroxide and Curing Method on the Compressive Strength of Ternary Blend Geopolymer Concrete. IOP Conf. Ser. Earth Environ. Sci. 2017, 80, 012011. [CrossRef]

44. Tran, T.T.; Pham, T.M.; Hao, H. Effect of hybrid fibers on shear behaviour of geopolymer concrete beams reinforced by basalt fiber reinforced polymer (BFRP) bars without stirrups. Compos. Struct. 2020, 243, 112236. [CrossRef]

45. Słowik, M. The analysis of failure in concrete and reinforced concrete beams with different reinforcement ratio. Arch. Appl. Mech. 2019, 89, 885-895. [CrossRef]

46. Jhatial, A.A.; Sohu, S.; Bhatti, N.; Lakhiar, M.T.; Oad, R. Effect of steel fibres on the compressive and flexural strength of concrete. Int. J. Adv. Appl. Sci. 2018, 5, 16-21. [CrossRef]

47. Yao, W.; Li, J.; Wu, K. Mechanical properties of hybrid fiber-reinforced concrete at low fiber volume fraction. Cem. Concr. Res. 2003, 33, 27-30. [CrossRef]

48. Sivakumar, A. Influence of hybrid fibres on the post crack performance of high strength concrete: Part I experimental investigations. J. Civ. Eng. Constr. Technol. 2011, 2, 147-159.

49. Lehmann, M.; Głodkowska, W. Shear Capacity and Behaviour of Bending Reinforced Concrete Beams Made of Steel FibreReinforced Waste Sand Concrete. Materials 2021, 14, 2996. [CrossRef]

50. Smarzewski, P. Hybrid Fibres as Shear Reinforcement in High-Performance Concrete Beams with and without Openings. Appl. Sci. 2018, 8, 2070. [CrossRef]

51. Hameed, A.A.; Al-sherrawi, M.H. Influence of Steel Fiber on the Shear Strength of a Concrete Beam. Civ. Eng. J. 2018, 4, 1501-1509. [CrossRef] 
52. Dev, A.; Chellapandian, M.; Prakash, S.S. Effect of Macrosynthetic and Hybrid Fibers on Shear Behavior of Concrete Beams Reinforced with GFRP Bars. J. Bridg. Eng. 2020, 25, 04020031. [CrossRef]

53. Majdzadeh, F.; Soleimani, S.M.; Banthia, N. Shear strength of reinforced concrete beams with a fiber concrete matrix. Can. J. Civ. Eng. 2006, 33, 726-734. [CrossRef]

54. Swamy, R.N.; Al-Taan, S.A. Deformation and ultimate strength in flexure of reinforced concrete beams made with steel fibre concrete. ACI J. 1981, 78, 395-405. 